\title{
ON ESKER FORMATIONS IN NOUSIAINEN, SW-FINLAND
}

\author{
Gunnar Glückert and Osmo Kontturi
}

\begin{abstract}
Glǘckert, Gunnar and Kontturi, Osmo 1972: On esker formations in Nousiainen, SW-Finland. Bull. Geol. Soc. Finland 44, 1-7.
\end{abstract}

\begin{abstract}
Two broken radial esker formations with small transversal ridges in the commune of Nousiainen in SW-Finland were the objects of the present investigation. These esker systems follow the principal directions of preglacial fracture zones of the bedrock in the area. The fracture valleys and the stratigraphy of the bedrock have locally turned the movement of the continental ice and caused transverse cracs in the ice. Many ridges of the radial esker complexes are deposited in crevasses and tunnels almost in a right angle to the principal ice movement. Under clay and silt deposits there are invisible glaciofluvial accumulations and they can be found only by drilling or seismic sounding methods.
\end{abstract}

\begin{abstract}
Gunnar Glückert, Institute of Quaternary Geology, University of Turku, 20500 Turku 50, Finland.

Osmo Kontturi, Department of Geography, University of Turku, 20500 Turku 50, Finland.
\end{abstract}

\section{Introduction}

This article is a report of an investigation on the occurrence, material and genesis of the radial and transverse esker-like glaciofluvial formations in the commune of Nousiainen, north of the town of Turku in SW-Finland. In the cultivated western part of the commune, the most noticeable radial esker system, the TurkuMynämäki-Laitila-Pyhäranta formation, runs across the investigation area. In the rocky middle and eastern parts of the commune there are two broken radial esker complexes with small transverse ridges. These broken systems, stretching from Alakylä to Kyläsuo, Kausvuori and Paistanoja (I in Fig. 1), and from Nälkänummi to Papumäki and Riitalho (II), were the objects of the present investigation.

The topography of the landscape is varying, consisting of cultivated depressed fields and rocky areas abounding in forests. The highest elevations in the area, $72-74 \mathrm{~m}$ a.s.1., occur north of Paistanoja (Kellarivuori) and in the Nälkänummi-Papumäki area (Mulkkivuori) and 


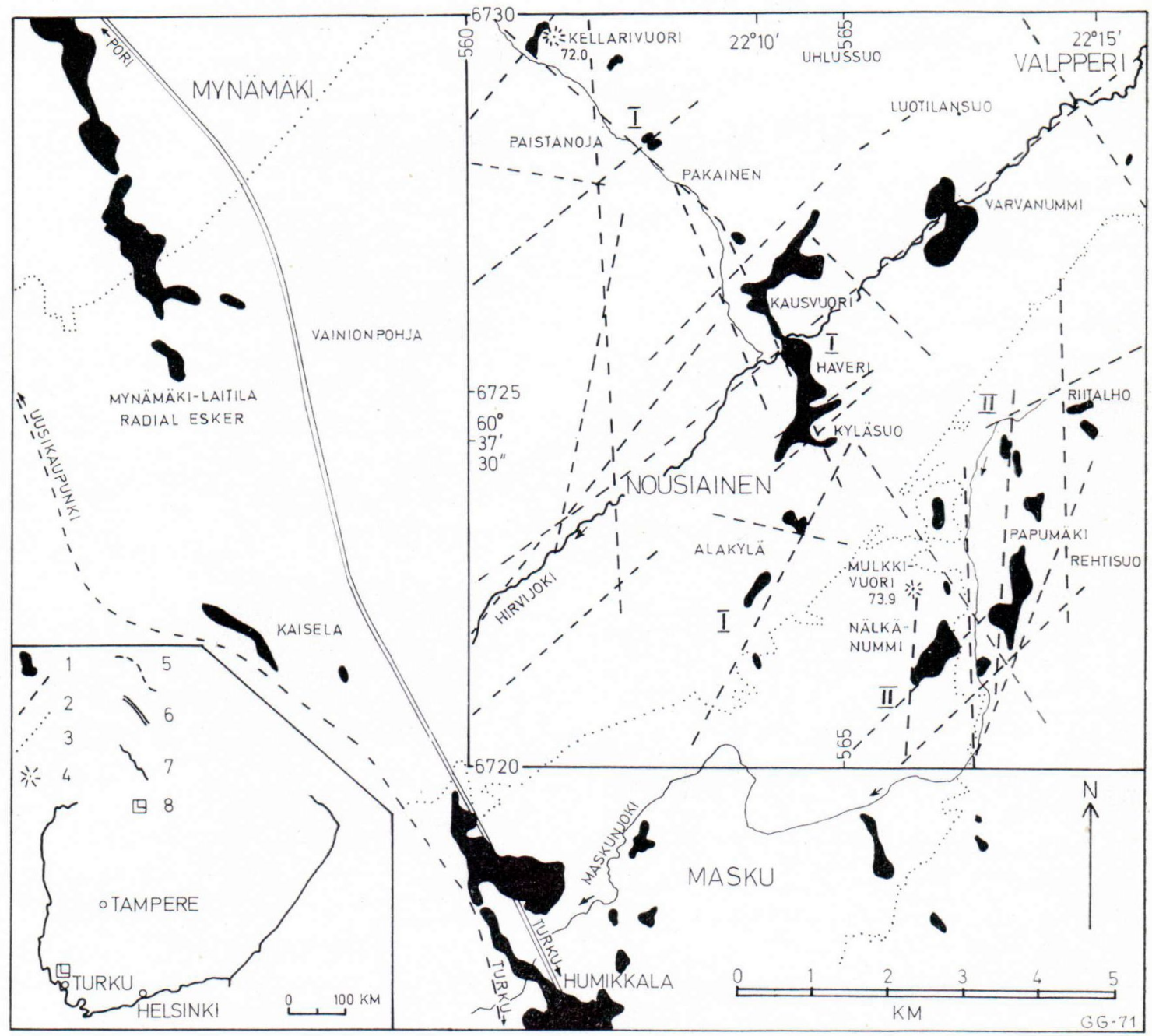

Fig. 1. Map showing the investigation area in southwestern Finland. $1=$ esker formation and glaciofluvial accumulation, $2=$ fracture valley, $3=$ border of commune, $4=$ highest point of rock, $5=$ railway, $6=$ road, $7=$ river, $8=$ the smaller area enlarged is investigated closer (Fig. 2), I = the Alakylä-Kyläsuo-KausvuoriPaistanoja radial esker system, II $=$ the Nälkänummi-Papumäki-Riitalho radial esker system.

the lowest ones, $5-6 \mathrm{~m}, \mathrm{SW}$ of Nousiainen. The fields in the valleys lie between 10 and $30 \mathrm{~m}$ and the rocky regions between 25 and $55 \mathrm{~m}$ a.s.l. The average differences in relative local elevation vary from 20 to $40 \mathrm{~m}$.

\section{Bedrock and Quaternary deposits}

According to Anna Hietanen (1947) and Härme (1960), mica shists and mica gneisses are predominant rocks in the area of Nousiainen. The dips of the foliation and bedding of the bedrock often are very steep, mostly $60-80^{\circ}$. The general strike of the rocks is approximately N $60-75^{\circ}$ E.

The rock crust of Finland is broken into a mosaic of pieces forming fracture zones which now occur as shear valleys. The principal directions of the shear zones in the area are NE-SW, $\mathrm{NW}-\mathrm{SE}$ and $\mathrm{N}-\mathrm{S}$. Many of them represent 
preglacial fracture valleys, long and deep and filled with clay and silt. These valleys are widest at places where two or more fault lines cross each other. The foliation of the bedrock often joins the NE-SW orientated fault systems. Bedrock outcrops seldom occur in these crossing fault lines and large valleys, e.g. the one between Nousiainen and Valpperi (the Hirvijoki valley), which is also partly due to the thick layers of surficial minerogenic deposits. The net slip of the main fault lines is presented in the map in Fig. 1. They are partly based on topographic maps, scale 1: 20000 , on the morphological observations in the field, and on the maps of fault lines prepared by Härme (1960, 1961).

The predominant minerogenic Quaternary deposit in the investigation area consists of clay and silt accumulations. These fertile sediments are laid down in valleys, e.g. in Paistanoja along the river Hirvijoki and in Pakainen and Papumäki along the river Maskunjoki. The next common minerogenic deposit is till, which generally underlies the other surficial deposits. Till deposits form a thin waterwashed cover over the crystalline bedrock, and this cover also conforms to the relative elevations of its rock base. In the right angle to the ice movement, independent moraine formations, such as end moraine ridges, occur e.g. in the regions of Pakainen, Kyläsuo and Riitalho. Some peat bogs, e.g. Uhlussuo, Luotilansuo and Rehtisuo, not very large in extent, are concentrated in an area $\mathrm{N}$ and $\mathrm{SE}$ of the investigation area (Fig. 1 and 2).

\section{Glaciofluvial accumulations}

Glaciofluvial accumulations have the largest extent of the surficial minerogenic deposits in Finland (Okko 1961 p. 25). Glaciofluvial drift occurs especially in the coast regions of the country in small quantities. E.g. in the Uusimaa administrative district in Finland, it amounts only to $3.1 \%$ of whole the land area (Frosterus 1921 p. 4). According to Moberg (1890 p. 56) and Aarnio (1930 p. 2) there are only few glaciofluvial deposits in the surroundings of Turku. On the other hand, plenty of small local occurences of stratified drift have been found in connection with the soil mapping of the Quaternary deposits in the area (see Lounais-Suomen Seutukaavaliitto 1968 p. 4 and 1969 p. 34) (Fig. 1 and 2).

The glaciofluvial deposits have different shapes, such as short ridges, hillocks and low, widely spread sandy accumulations mostly lying as infillings of depressions between rocks. Many small glaciofluvial accumulations, belonging to the broken systems investigated, can be found along the flanks of the rocks, and many of them could be interpreted as formations resembling shore deposits. The narrow ridges are often deposited on the bottoms of fracture valleys. Between Kausvuori and Haveri, a ridge formed accumulation can be found crossing the shear valley of the Hirvijoki. Especially in the zones of both the esker systems there are invisible sand and gravel deposits under the thin clay and silt sediments, most of which can be found only by drilling or seismic sounding methods (Fig. 2).

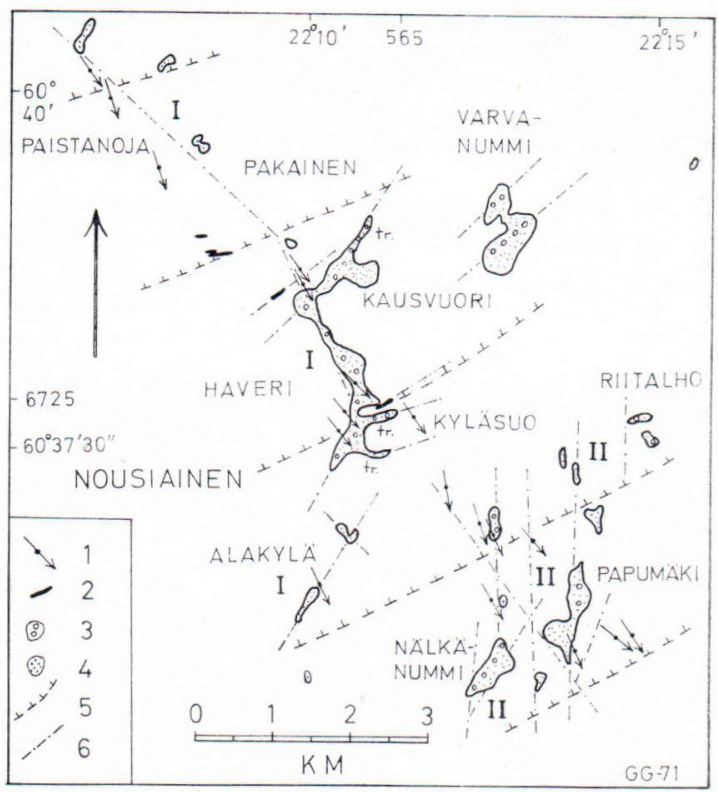

Fig. 2. Area investigated closer. $1=$ striae observation, $2=$ end moraine, $3=$ gravel and pebbles, $4=$ sand, $5=$ position of retreating ice margin, $6=$ crevasses and tunnels in the ice margin following fracture zones, $\mathrm{tr}=$ transverse esker, I and II, see Fig. 1. 


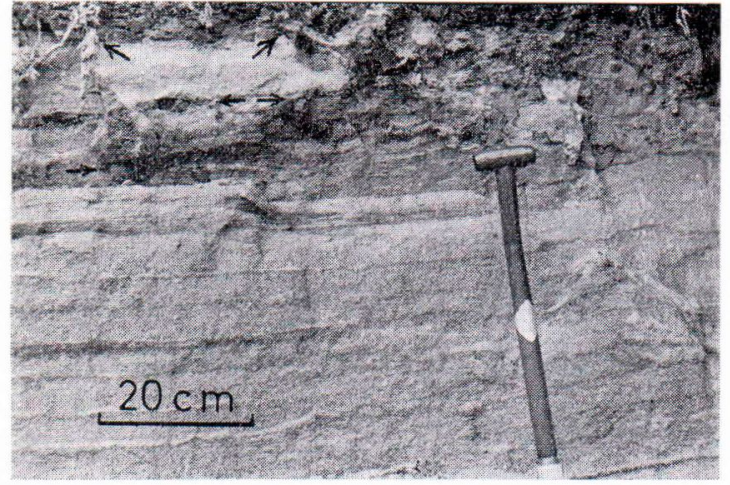

Fig. 3. Thin layers of clay (arrows) and silt overly the primary glaciofluvial sandy drift of the core in the radial esker of Kyläsuo. Photo G. Glückert 29.1.1971.

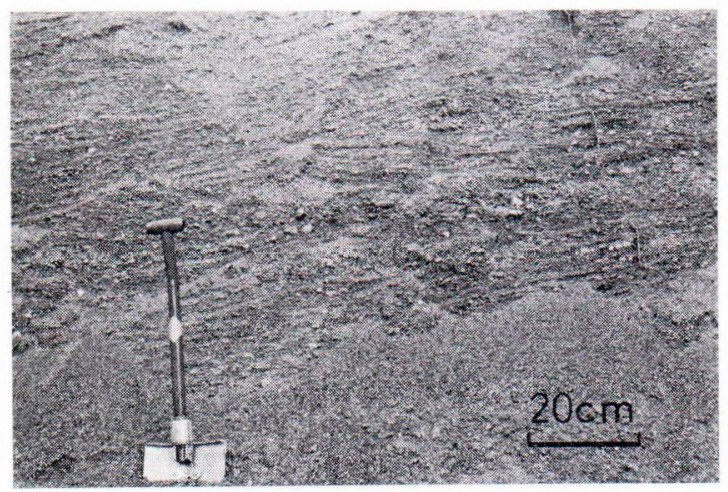

Fig. 4. Stratified sandy gravel in the Kyläsuo radial esker Photo G. Glückert 29.1.1971.

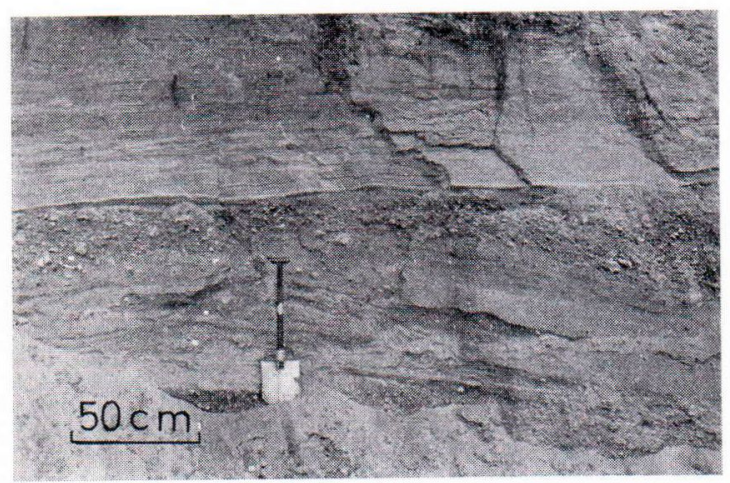

Fig. 5. Fine sand overlying stratified pebbly sand and gravel in the northern transverse esker of Kyläsuo. Photo G. Glückert 29. 1. 1971.
On high elevated lands and rocky uplands, e.g. those SE from Kausvuori and in the HaveriKyläsuo region, the glaciofluvial drift was laid down as irregular hills, thin extensive coverings on rocks and infillings between the tops of the rocks.

According to Hyyppä (1966 p. 160) the general position of the retreating ice margin ran over the area during the stage BII of the Baltic Ice Lake in the history of the Baltic Sea, about 8200 years B.C. The forms of all glaciofluvial accumulations in the investigated area have become strongly deformed and more even in connection with the melting of the ice and later with the shore activity of the stages of ancient Baltic Sea. Extensive sandy plains can be found in Kausvuori and at the S end of the Papumäki formation (Fig. 2).

\section{Material}

The main mechanical composition of the drift, devided into fine (sand) and coarse (gravel and pebbles) material, is marked separately in each formation in Fig. 2. Most ridge-shaped accumulations are built up of washed sand and gravel. Homogeneous sandy shore deposits overly a thin layer of clay, and the latter lies above the stratified primary drift. The surface beds of the sand plains in Kausvuori and Papumäki formations consist of typical fine sand, but coarser primary drift can be found in the deeper, basal layers of the core (Fig. 3, 4 and 5).

In the area investigated, sand and gravel deposits are in general $2-5 \mathrm{~m}$ thick. The $5-10 \mathrm{~m}$ heavy accumulations of Haveri and Nälkänummi made the only exception. According to the material inventory of these deposits, the largest formations in Haveri and Nälkänummi originally consisted of c. $120000-150000 \mathrm{~m}^{3}$ sand and gravel (see Kontturi 1971 p. 39). These sand and gravel resources have strongly decreased, owing to the noticeable exploitation during the last few years. In Haveri they now amount to c. 100000 $\mathrm{m}^{3}$ and in Nälkänummi to c. $60000 \mathrm{~m}^{3}$. The 
material has been used mostly to road construction and house building activity (Fig. 6).

Technically useful material can be found in the formations of Alakylä, Kausvuori and Kyläsuo, c. $30000 \mathrm{~m}^{3}$ in each. The large, thin covered sand deposits of Varvanummi can be reserved e.g. as protection areas of ground water resources or refreshment areas. The core of this formation consists of c. $25000 \mathrm{~m}^{3}$ of technically useful coarse material, the other sand and gravel accumulations in the region are quite small and of poorly sorted drift. They are only of a local importance in the view of total sand and gravel consumption.

\section{Genesis}

The influence of the topography of bedrock to the regional distribution of eskers in the landscape has earlier been discussed e.g. by Strandmark (1889), Leiviskä (1928), Brenner (1944), Hyyppä (1954), Eriksson (1960) and Aartolahti (1968). The foliation and bedding as well as the fault zones have a local influence to the movements of the ice and thus to the distribution and orientation of the esker formations in Nousiainen. According to the observations of striations in the area, the direction of the ice movement has been from NNW or $320-350^{\circ}$ (Fig. 7). The varying relief and stratigraphy of the bedrock in Alakylä, Nälkänummi and Papumäki has caused in the ice margin several cracs in the directions of the valleys in spite of the different main direction of the ice movement (Fig. 1 and 2).

According to the general opinion the main esker systems follow the trends of fault lines, and the formation of eskers is in genetic relation to the crustal movements. The esker have been formed in radial fractures of the bedrock, and these fractures were caused by the block movements of the earth's crust (Hyyppä 1954, Granö 1958, Ohlson 1958, Härme 1961 and Kukkonen 1969).

The $4 \mathrm{~km}$ long main esker formation of the system I in Nousiainen lies between Kyläsuo,

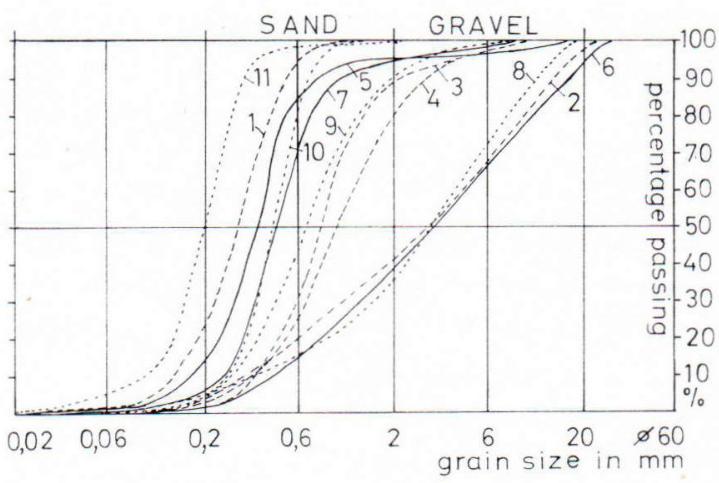

Fig. 6. Cumulative grain size curves presenting the mechanical composition of stratified material in the esker formations of Papumäki (1-4), Kyläsuo (5-7) and and Alakylä (8-11). Anal. O. Kontturi.

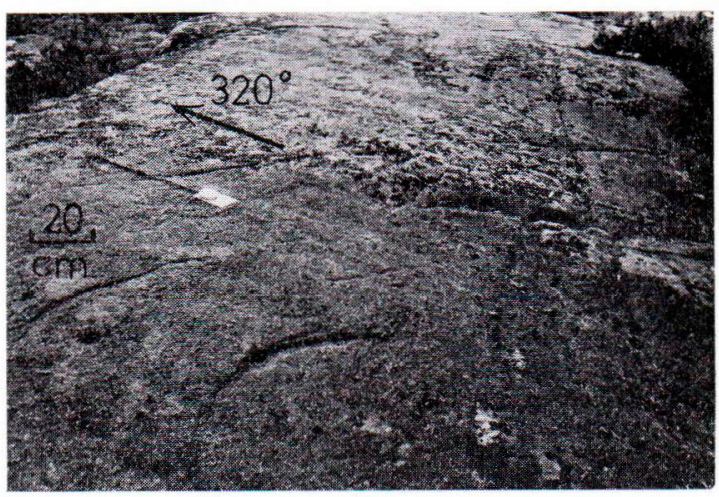

Fig. 7. Glacial striation $\left(320^{\circ}\right)$ and crescentic gouges on gneissose bedrock in Kyläsuo, Nousiainen. Photo G. Glückert 15. 12. 1970.

Haveri and Kausvuori. Parallel to the radial Mynämäki-Laitila esker and the ice movement, the Kyläsuo-Kausvuori complex was deposited along one of the most noticeable fracture valleys between Kyläsuo, Kausvuori and Paistanoja (Fig. 1 and 2). This esker formation was mainly due to the differences between the bedrock topography and the speed of the movement of the ice in the valley and on both its sides (Okko 1945 p. 47). This caused cracs and crevasses in the ice just on both sides of the valley. E.g. in Alakylä the glaciofluvial accumulations occur on the western side of the NE-SW orientated valley and in Paistanoja on the eastern side of the NW-SE directed valley. 
The direction of the retreat of the continental ice sheet in the region is characterized by numerous striaes on bedrock exposures, small end moraines and some radial and transverse esker formations (Fig. 2). The retreat of the ice margin did not take place continuously. There were halts of short durations, when the material was deposited subaquatically in open transverse crevasses and tunnels of the thinning tongue of the ice sheet. No separate advances of the ice have been noticed in the area investigated.

The NW-SE orientated Kyläsuo-Kausvuori radial esker is connected with three short lateral ridges running in the directions of the transverse or NE-SW directed fracture lines (tr. in Fig. 2). They can be considered as transverse or lateral eskers, and they were formed subglacially by the cracing of the ice (Hyyppä 1954 p. 45, Eriksson 1960 p. 70, Virkkala 1961 pp. 235-239, 1963 pp. $42-44$ and Aartolahti 1968 pp. 46-48). The formation of these transverse eskers can be connected with some transverse cracs in the tunnel walls and crevasses, when the ice began to calve. These cracs were filled with glaciofluvial material. Thus the lateral ridges mostly contain wellwashed and sorted drift. Sometimes the drift in the core resembles to some extent waterwashed, poorly sorted till, and the ridges then resemble end moraines (e.g. in Kyläsuo). According to Tanner (1938 pp. 513 - 514) the transverse eskers are deposited at the margin of the ice in transverse cracs or other transverse depressions.

The deposits of the broken radial KyläsuoKausvuori (I) and the separate ridges of the
Nälkänummi-Papumäki esker systems (II) were finally laid down by glaciofluvial meltwater streams near the opening of ice tunnels or open crevasses at the margin of the slowly retreating ice (see Okko 1945 pp. 50-53 and Aartolahti 1968 pp. 40-45). These eskers consist of quite typical stratified sands and gravels (Fig. 3-5).

The Papumäki and Nälkänummi radial formations in the Maskunjoki fracture valley lie almost in a $\mathrm{N}-\mathrm{S}$ direction or in a right angle to the glacial striation. In this area, however, the broken tectonic of the bedrock has to some extent changed the deposition of the material and the distribution and orientation of separate accumulations (Fig. 1 and 2).

The local topography impeded and slowed up the flow of the glaciofluvial river by forming extensive deposits on high elevated rocks, and plenty of drift spread on large areas (e.g. Kausvuori). Besides, an esker branches more often on uneven base than on even topography (Eriksson 1960 p. 59).

One of the most extensive glaciofluvial accumulation in the investigation area, the Varvanummi formation, was formed in a more complicated manner than it was assumed earlier (see Moberg 1890 p. 58 and Ohlson 1958 p. 14). According to the stratigraphy, the Varvanummi formation has taken the shape of two separate, transverse ridges lying on both sides of the river Hirvijoki. These glaciofluvial ridges were smoothed to an extensive sand plain and later cut into two parts by the river erosion.

\section{REFERENCES}

Aarnio, B., (1930) Turku. Agrogeologisia karttoja No. 6. Helsinki.

Aartolahtr, Toive (1968) Die Geomorphologie des Gebiets von Tammela, Südfinnland. Fennia 97, 7, pp. 1-97.

BRENNER, THORD (1944) Finlands åsars vittnesbörd om ytgestaltningen hos landisen. Zusammenfassung: Die Osen Finnlands als Zeugen der Oberflächengestaltung des Landeises. Fennia 68, 4, pp. 1-39.
Eriksson, K. Gösta (1960) Studier över Stockholmsåsen vid Halmsjön. Summary: Studies of the Stockholm ose at Halmsjön, Uppland, Sweden. Geologiska Fören. i Stockholm Förhandl. Bd. 82, 1, pp. 43-125.

Frosterus, Benj., (1921) Jordarternas areal i Nylands län. Fennia 42, 7, pp. 1-12.

Granö, Olavi (1958) The Vessö esker in southern Finland and its economic importance. Fennia 82, 1, pp. $1-33$. 
Hietanen, Anna (1947) Archean geology of the Turku district in southwestern Finland. Bull. Geol. Soc. America 58, pp. 1019-1084.

Hүyppä, EsA (1954) Åsarnas uppkomst. Geologi 6, 5, p. 45.

- (1966) The Late-Quaternary land uplift in the Baltic sphere and the relation diagram of the raised and tilted shore levels. Annales Acad. Scient. Fenn., Ser. A, III, 90, pp. 153-168.

Härme, Maunu (1960) Suomen geologinen yleiskartta. The general geological map of Finland. Lehti-sheet B1, Turku. Kivilajikartan selitys. English summary. Geologinen tutkimuslaitos (The Geological Survey of Finland), pp. $1-78$.

- (1961) On the fault lines in Finland. Bull Comm. géol. Finlande 196, pp. 437-444.

Kontturi, Osmo (1971) Maskun ja Nousiaisten soran kulutuksesta. Summary: On determining the gravel consumption in the communes of Masku and Nousiainen in S.W. Finland. Turun Ylioppilas XV, pp. 3556.

Kukronen, EsA (1969) Merenalainen harjujakso Porin edustalla. Summary: On the submarine esker in the Bothnian Sea. Geologi 21, 5, pp. 65-69.

Lerviskä, I., (1928) Über die Ose Mittelfinnlands. Die Entstehung des Materials und der Formen der Ose. Fennia 51, 4, pp. $1-207$.

Lounais-Suomen Seutukaavalirtro (The regional planning association of South-West Finland) (1968) Geo- logisen maaperätutkimuksen selitys 1966-67 TurunMynämäen - Uudenkaupungin - Auran - PaimionSauvon alueilla. Maaperätutkimus 1966-67. Moniste (mimeographed), pp. 1-58.

- (1969) Lounais-Suomen sora- ja hiekkavarat 1969. Perustutkimukset, 3. Moniste (mimeographed), pp. $1-64$.

Mober G, K. Ad., (1890) Kertomus karttalehteen no. 10, Turku. Suomen geologinen tutkimus. Helsinki, pp. $1-76$.

Ohlson, Birger (1958) Om Åbo stads försörjning med sand och grus. Skriftserie utgiven av Handelshögskolan vid Åbo Akademi B: 15, pp. $1-29$.

Oкко, Veıkко (1945) Untersuchungen über den MikkeliOs. Fennia 69, 1, pp. 1-55.

- (1961) Der Mensch als Gestalter der Oberfläche des finnischen Festlandes. Fennia 85, pp. 24-41.

Strandmark, P. W., (1889) Om jökelelfvar och rullstensåsar. Geologiska Fören. i Stockholm Förhandl. Bd. XI, pp. 93-111.

TANNER, VÄINÖ (1938) Die Oberflächengestaltung Finnlands. Bidrag till kännedom av Finlands natur och folk 86 , pp. $1-762$.

VIrkKaLA, K., (1961) On the glacial geology of the Hämeenlinna region, southern Finland. Bull. Comm. géol. Finlande 196, pp. 215-242.

- (1963) On ice-marginal features in southwestern Finland. Bull. Comm. géol. Finlande 210, pp. 1-76.

Manuscript received, February 15, 1971. 